\title{
LEGAL CULTURE OF PHARMACIST IN THE PERSPECTIVE OF PHARMACEUTICAL SERVICES STANDARD IN PHARMACIES ${ }^{\Omega}$
}

\author{
Endang Sutrisno and Hanari Fajarini \\ Postgraduate School of Universitas Swadaya Gunung Jati Cirebon \\ E-mail: endangsutrisno94@gmail.com
}

\begin{abstract}
Pharmacists are burdened with obligations as cited in Regulation of the Minister of Health, No. 35 of 2014 on the Standards of Pharmaceutical Services in Pharmacy. This paper uses socio-legal approach aiming at examining the norms associated with the protection of the patient's safety. The applicability of the rules faces some obstacles since the legal culture of apathy still exist, so that the understanding and awareness of legal compliance is not achieved. Legal culture of apathy regarding ideas, concepts, perceptions, views, values and behaviors that are not constructive, affect the workings of law towards the observance and compliance to the law, as a result, the purpose of the law to provide justice and legal certainty to the practicians suchas pharmacists, patients and owner of the pharmacy services, are not fully able to interpret the substance of the regulation of the Minister of Health, Number 35 of 2014. As a result of this legal culture, the implementation of the Regulation of the Minister of Health No. 35 of 2014 is directed more on aspects of benefactive purpose than on the aspect of legal certainty.
\end{abstract}

Keywords: pharmacists; apathy legal culture; the purpose of law.

\begin{abstract}
Abstrak
Apoteker dibebani dengan kewajiban dalam Peraturan Menteri Kesehatan RI Nomor 35 Tahun 2014 tentang Standar Pelayanan Kefarmasian di Apotek. Tulisan ini menggunakan pendekatan socio-legal dengan tujuan menelaah norma dikaitkan dengan perlindungan keselamatan pasien. Keberlakuan kaidah mengalami hambatan karena budaya hukum apatis sehingga pemahaman kesadaran dan kepatuhan hukum tidak tercapai. Budaya hukum apatis berkenaan dengan ide, gagasan, persepsi, pandangan serta nilai dan perilaku yang tidak konstruktif sehingga mempengaruhi proses bekerjanya hukum, terhadap ketaatan, kepatuhan pada hukum akibatnya tujuan hukum untuk keadilan dan kepastian hukum para pelaku yaitu apoteker, pasien serta Pemilik Sarana Apotek tidak sepenuhnya mampu menterjemahkan teks-teks dari substansi muatan Peraturan Menteri Kesehatan RI Nomor $35 \mathrm{Ta}$ hun 2014. Akibat budaya hukum ini, maka penerapan Peraturan Menteri Kesehatan RI Nomor $35 \mathrm{Ta}$ hun 2014 lebih diarahkan pada aspek tujuan kemanfaatan dari pada aspek kepastian hukum.
\end{abstract}

Kata kunci: apoteker; budaya hukum apatis; tujuan hukum.

\section{Introduction}

Pharmacy services previously only focused on the management of drug (drug oriented), now transformed into a comprehensive service which has a goal to improve the life quality of patients. As a result, the existence of pharmacists have demand in the context of human resource development to increase the ability of the knowledge acquisition, skills and able to change the behavior in terms of interaction with

\footnotetext{
$\Omega$ This article is part of the personal research that was conducted in 2015
}

patients. Forms of interaction are drug information service, drug counseling, home care, therapeutic drug monitoring and monitoring drug side effects.

Government Regulation Number 51 Year 2009 concerning Pharmaceutical Works, give the meaning of Pharmaceutical Services as a service that directly responsible to the patient and have an associated with a pharmaceutical preparation with a view to achieve certain results that improve the quality of life of patients. Technically, those regulation is supported by the Minister of Health Regulation No. 35 Year 
2014 concerning Standards of Pharmaceutical Services in the pharmacy, with the aim to provide protection against the patient's safety. For that reason, all pharmacy personnel in performing the tasks profession must refers to the standard that already been set. The enforceability of legal norms referred to the concept of state law and all of those activity should be based on the law. ${ }^{1}$

In fact, pharmacy services in pharmacies just focused on the implementation of buying and selling drugs, meanwhile the important aspects that regulated in standard pharmacy services are ignored. One of them is the Drug Information Service, the activities that carried out only in terms of information about buying or selling drugs. Though essentially of Drug Information Service is a comprehensive information service related to drugs, including the rules of use, how to consumed/route of drugs, indications, contraindications, the possibility of interactions that occur, as well as side effects.

Based on information from the Chairman of Indonesian Pharmacist Association Branch Executive of Brebes, pharmacy services at home (home pharmacy care) and medication record until now has not been implemented maximally. Home pharmacy care is actually necessary to provide pharmaceutical services especially for degenerative patients who need long-term care time, for example: patients with tuberculosis, hypertension, cardiovascular disease, diabetes mellitus, or to provide services for patients who do not have time to come to the pharmacy. Medication records can be used to obtain the accurate data of patient, especially for patients who have repeatability of treatment. Moreover, statistics medication data record can be used as an valid evidence if there is a lawsuit against pharmaceutical services in pharmacies.

During this time, pharmacy services are still below the minimal standards. Head of Pharmacy Section of Health Agency Brebes District said that Pharmacists should have a central role

Rahman Yasin, "Telaah Putusan MK dalam Sengketa PHPU Pilpres 2004 (Perspektif Negara Demokrasi Konstitusional)", Jurnal Konstitusi, Vol. 11 No. 4, December 201, Jakarta: Mahkamah Konstitusi Republik Indonesia, page 652 . and take full responsibility in providing pharmacy services to patients, but in fact the standard implementation of pharmacy services not been conducted maximummly, even many Pharmacist of Pharmacy business which is not located in pharmacies when the pharmacy opening hours. On another chance, pharmacy services under these standards significantly expressed key informants of Branch Executive Chairman of Indonesian Pharmacist Association of Brebes, state that $70 \%$ of pharmacies in Brebes not apply good standard pharmaceutical services.

\section{Problems}

This article will discuss abaut: first, how does the standard implementation of pharmacy services in pharmacies? and second, how does the legal culture of the pharmacist in the standard approach to pharmacy services in pharmacies?

\section{Research Methods}

The approach used in this study is sociolegal research which classified in term of case study or field study. This clasification analyse the legal culture of apathy pharmacist with the emphasis on learning from the people intensively study and assess the condition of social setting and social interaction built by pharmacists in the implementation of the standard pharmaceutical services in pharmacies. Qualitative data used to emphasis the whole phenomenon of the pharmacist in pharmaceutical services to implement the action that are influenced by the legal culture is formed, in the daily activities are particularly relevant to the standard issue service of pharmacy. Data validation using snowball sampling method related to enforceability of the Minister of Health Regulation Number 35 Year 2014 as the basic norms to regulate the patient's pharmacist and pharmacy owner facilities. Based on that reason, this reserach used data validation in the form of source triangulation. Location research was in Brebes with the reasoning from the results of presurveys still commonly found social conditionssetting pharmacy that only have one pharmacist, this has resulted the emergence of obstacles in carrying out the counseling, monitoring, 
preparation and management of the drug at once, on the other hand still must perform pharmacy services at home (home care pharmacy).

\section{Discussion}

The Implementation of Standard Pharmaeutical Service in Pharmacy for the Safety Protection of Patient

The purpose of law according to the utility theory which pioneered by Jeremy Bentham is to ensure the greatest happiness for humans in quantities as much as possible (the greatest happines for the greatest number). So in essence the law is used to produce the maximum pleasure or happiness for the largest number of people $^{2}$. In line with the objectives of the law enforcement standard pharmaceutical services mandatory, intended to provide safety protection to the patient in order to obtain the greatest happiness.

According to Esmi Warassih, the law is not only used to regulate behavior in society and as a means of social control, but the law also be used as a means to make a change in society ${ }^{3}$. Law thus have functions that are urgent, there are 4 (four) model law which is known, first, models of highly repressive colonial laws; second, the legal model of development; third, the model of progressive law; and fourth, the model of integrative law. ${ }^{4}$

Related efforts to achieve an effective legal system needs institutional restructuring of the law which is supported by the quality of human resources and culture and public legal awareness that continues to increase, along with the renewal of legal materials are structured harmoniously without contradiction and overlapping and legal continuously updated in accordance the demand of development needs ${ }^{5}$.

Esmi Warassih, 2014, Pranata Hukum Sebuah Telaah Sosiologis, Semarang: Suryandaru Utama, page 20.

\section{Ibid, page. 96}

4 Romli Atmasasmita,"Tiga Paradigma Hukum dalam Pembangunan Nasional", Jurnal Hukum Prioris, Vol. 3 No.1, Year 2012, Jakarta: Faculty of Law Universitas Trisakti, page 5.

5 Bahria Prentha, "Filsafat Hukum dan Nilai-Nilai Pancasila", Jurnal Ilmiah Kebijakan Hukum, Vol. 5 No. 2 August 2011, Jakarta: Pusat Pengkajian dan Pengembangan Kebijakan Kementerian Hukum dan HAM RI, page 177.
It must be realized that to create the legal justice, it necessary an active role from the various parties ranging from the establishment of a legal product until product of law enforcement. ${ }^{6}$ Law has sovereignty rests in the people's sovereignty, can be made "hypothesis" 7 that the legal sovereignty is not intended solely for the benefit of the law itself, but rather must be aimed and aligned to the interests of society.

Law in the form of the legislation, product policy should be understood in its realization in all jurisdictions-and in all steps is supposed to be an entity that is authentic. ${ }^{8}$ Law in the form of product policies such legislation, must be understood in the realm of law in all manifestations and in all steps should be an authentic entity. Meanings of authentic here is sensed as a genuine entity in accordance with the nature existence, follow the though of Gustav Radbruch ${ }^{9}$ thought the existence nature of the law can be simplified into a number of objectives to be achieved, namely the law of fairness, certainty and expediency ${ }^{10}$

It is realized that $r$ the development of law in this country tends to move in an artificial space and without direction. ${ }^{11}$ Indonesia today

6 Yunus Bureni, “Moralitas Pembentukan Peraturan Daerah dalam Upaya Mencapai Keadilan Substantif (Morality Formation of Local Regulations in An Effort to Ensure Substantive Justice)", Jurnal Legislasi Indonesia, Vol. 10 No. 2, June 2013, Jakarta: Direktorat Jenderal Peraturan Perundang-undangan Kementerian Hukum dan HAM RI, page 125 .

7 Bambang Widjojanto, "Negara Hukum, Korupsi dan Hak Asasi Manusia: Suatu Kajian Awal”, Jurnal Hukum Prioris, Vol. 3 No. 1 Year 2012, Jakarta: Faculty of Law Universitas Trisakti, page 30.

8 Endang Sutrisno, "Role of law in construction and development of small scale industries through normative perspective", Jurnal Dinamika Hukum, Vol. 15 No. 3, September 2015, Purwokerto: Faculty of Law Universitas Jenderal Soedirman, page 319.

9 Endang Sutrisno, "Implementasi Pengelolaan Sumber Daya Pesisir Berbasis Pengelolaan Wilayah Pesisir Secara Terpadu untuk Kesejahteraan Nelayan (Studi di Perdesaan Nelayan Cangkol Kelurahan Lemahwungkuk Kecamatan Lemahwungkuk Kota Cirebon)", Jurnal Dinamika Hukum, Vol. 14, No. 1, January 2014, Purwokerto: Faculty of Law Universitas Jenderal Soedirman Purwokerto, page 9.

10 Yudi Kristiana, "Ketika Hukum Tidak Lagi Otentik”, Jurnal Hukum Supremasi, Vol. IV, No. 1, Oktober 2010March 2011, Jakarta: Pusat Studi Hukum Bisnis Fakultas Hukum Universitas Sahid, hlm 741-742.

11 Dayanto, "Rekonstruksi Paradigma Pembangunan Negara Hukum Indonesia Berbasis Pancasila", Jurnal Dinamika 
is faced with a very "unique" problem of law performance regarding the formal truth treated as the most dominant consideration of legal decision, based on reine Rechtslehre Kelsenian's way of thinking. An approach that is still in further discussion through a more holistic alternative paradigm. ${ }^{12}$ The teachings of monistic legal positivism, which recognizes only one kind of justice, namely justice was born from positive law. ${ }^{13}$

As an approach, it also found in the implementation of standard of pharmacy services as regulated by Health Minister Regulation 35 Year 2014, which should be assessed through legal awareness of the pharmacist. Lawrence $M$. Friedman said that legal awareness factor closely related to legal cultural issues, namely in the form category of values, views and attitudes that affect the operation of the law $^{14}$.

The standard implementation of pharmacy service to protect the safety of patient consist of recipes assessments; dispensing; Drug Information Service; counseling; pharmacy services at home (home care pharmacy); Therapeutic Drug Monitoring; and Monitoring Drug Side Effects (meso).

Based on observations and interviews, almost pharmacists do not verify the name of the doctor, (Session Initiation Protocol) SIP, address and telephone number of the doctor. The pharmacist is assumed that the the existence of doctor's name, SIP, address and telephone number on the recipe is not need to be rechecked. Though essentially the checking must be done to avoid the possibility of counterfeiting recipes.

Hukum, Vol. 13 No. 3, September 2013, Purwokerto: Faculty of Law Universitas Jenderal Soedirman, page 498.

12 Endang Sutrisno, "Tracing the Performance of Law in Indonesia (A Perspective of Thomas Kuhn's "Normal Science", Journal of Law, Policy and Globalization, International Institute for Science, Technology \& Education Accelerating Global Knowledge Creation and Sharing, Vol. 37. Year 2015. page 126.

13 Ibnu Artadi, "Dekonstruksi Pemahaman Penyelesaian Sengketa Bisnis (Ekonomi dan Keuangan) Beraspek Pidana melalui Prosedur Perdamaian: Menuju Proses Peradilan Pidana Rekonsiliatif", Jurnal Hukum Responsif, Vol. 1, No. 1, 2011, Cirebon: Faculty of Law Universitas 'Swadaya Gunung Jati Cirebon, pages 33-34.

14 Esmi Warassih, op.cit., page 72.
Another thing that was also ignored by the pharmacist was checking initials of the doctor. The validity of a recipes can be seen with the initials from the doctor prescribe, it because the doctor take full responsibility for everything that is written on the recipe. The pharmacist reasoned, if the need to check the recipe will require much time, while pharmacists are faced with various recipes while the human resources relating with pharmacies is limited. Based on the result, that not all of the activities in terms of clinical considerations conducted by pharmacists such as indication, dosage, rules and how to use the drug. They reasoned if it should be checked in all parts of the processing time for the one recipe it need much time.

Drug Information Service is an activity performed by pharmacists in providing information relating with drug impartial, critically evaluated and with the best evidence Ito other health professionals, patients or the public. Until now, drug information Service Activities has not run up maximally, because the activities are more focused on buying or selling drugs. The Important information regarding the dosage, dosage form, special formulation, route and method of administration, pharmacokinetics, pharmacology, therapeutic and alternatives, efficacy, safety of use to pregnant and lactating women, the side effects and drug interactions, sometimes ignored by the pharmacist. The pharmacist reasoned, if it should implement Drug Information Service, other activities relating to recipes services will be hampered. Less of human resources become main factor of job inefficency.

Normatively, Minister of Health Regulation Number 35 Year 2014 concerning Standards of Pharmaceutical Services in Pharmacy Services, also set about the activities of drug information service, promotion and educational activities. Promotion is an activity that empowers people by motivation through giving inspiration to the public, the aims is people are motivated to be able to improve the quality of life independently. Education is an activity that empowers public through giving relevant knowledge 
about medication therapy and involve patients in decision-making, which aims to medicinal purposes can be achieved optimally. Many health problems and medical problems can not be dealt with and solved in the doctor's office, out patient clinic or at the patient's home ${ }^{15}$

Home pharmacy care intended for elderly patients and patients with chronic diseases. Activities of pharmacy services at home completely have not been implemented by pharmacy which becoming research object, again the cost factor is a constraint in the implementation of pharmacy services at home.

Implementation Monitoring Drug Therapy activities not run optimally, it is because the limited time pharmacist to conduct monitoring activities to the patient because of work time pharmacist at the pharmacy which tends to be short, so that the activities of a pharmacist with more emphasis on service activities, such as service prescription and treatment services alone.

The Activity of Monitoring Drug Side Effects has not running optimally, this activity is constrained by the knowledge of the pharmacist in identified the risk of drug side effects to the patient. The reason was stated by the Chief Pharmacist Association Brebes, said that the interest pharmacist in Brebes to increase knowledge through seminars and other scientific activities are still low.

The Pharmacists Legal Culture in the Standard Approach of Pharmacy Pharmaceutical Services for the Protection of Patient Safety

Regulation regarding pharmacy services in the pharmacy are stipulated in Minister of Health No. 35 Year 2014. Based on the research found the tendency that such provisions are ignored by the pharmacists in providing pharmaceutical services to patients. Factors of limited number of human resources and factor of economic become the reason not to implemented

15 Nayla Alawiya, Aryuni Yuliantiningsih, Dessi Perdani Yuris Puspita Sari, "Hospital Supervisory Board Role in Medical Dispute Settlement in Hospital (Analysis toward Mechanism and Normative Obstacles)", Jurnal Dinamika Hukum, Vol. 15 No. 3, September 2015, Purwokerto: Facul-ty of Law Universitas Jenderal Soedirman, page 268. standard pharmacy services. Economic factors backed because most pharmacy are the property Owner Means Pharmacy, the pharmacist has a greater role as an employee rather than as a partner to the pharmacist does not have the authority to set the direction of pharmacy.

Beside the factor of Owner of Facility Pharmacy, a factor of ignorance and lack of understanding about Health Minister Regulation Number 35 Year 2014 becoming an factor which non-performance of standard pharmacy services. Both of these factors are influence the attitudes and behavior patterns of pharmacist in complying the law, these conditions create a legal culture pharmacist is not constructive. Components from the issue of law awareness is closely related to the cultural elements of the law that can be interpreted with the category of values, views and attitudes that affect the operation of law.

Based on research, it found the attitude/ behavior of pharmacist in the implementation of Health Minister Regulation law Number 35 Year $2014:{ }^{16}$ first, the rule of law to be applied, if remidia cardinal in the recipe checked one by one, recipes processing time may take much time, while completing recipes that very much every day. Initials of the doctors are not checked, it is not possible if the administration in the recipe is checked one by one. Second, the rule of law has not been optimally running, in part scrining of recipes, remidia cardinal is not checked, So even with an initials doctors and pharmaceutical studies have not held. Pharmaceutical studies have not done due to the limited number of human resources, in the end we believe only the prescribing doctor is correct in determining the form, potency and stability of drugs. Third, the Pharmacists already tried to carry out an assessment of prescription and dispensing. In the drug information service only briefly explains about the drug, usually only explained about the rules of use, if it should be

\footnotetext{
16 Interview with key informan, which were Pharmacist, Branch Executive Chairman of Indonesian Pharmacist Association (IAI) Brebes District and Head of Pharmacy Section of Health Agency Brebes District along with Pharmacy Owner (PSA), Period of February until May 2016.
} 
explained in detail is not possible because the pharmacist only a temporary one must also do the following of next recipes. Promotion and education are part of the Drug Information Service is merely banner slogan DAGUSIBU (Third, the Pharmacists already tried to carry out an assessment of prescription and dispensing. In the drug information service only briefly explains about the drug, usually only explained about the rules of use, if it should be explained in detail is not possible because the pharmacist only a temporary one must also do the following of next recipes. Promotion and education are part of the Drug Information Service is merely banner slogan DAGUSIBU Get Medicines in the pharmacy, Use By Wisely, Save On The Safe Place, Throw If Already Expired) or Get Medicines in the pharmacy, Use By Wisely, Save On The Safe Place, Throw If Already Expired.

The pharmacist attitude tend to apathetic, many provisions in the standard pharmaceutical services are not implemented, based on the difference in orientation between the pharmacist and The Owner Facility Pharmacy. Essentially the pharmacist wants to carry out what stated in Health Minister Regulation Number 35 Year 2014, it's just economic factors and patterns of working relationships between the pharmacist and the Owner Facility Pharmacy as subordinates and superiors give considerable influence in the implementation of this regulation. The pattern of working relationships between the pharmacist and the Owner Facility Pharmacy as a patron-client relationship. Friedman mentioned in connection of law effect with the acts of human attitudes can be classified into obedience or compliance, disobedience or deviation deviance and evasion. The classification relates to law that contains the prohibition or a messenger. But for the law containing the permissibility, the classification is the use, nonuse, and misuse ${ }^{17}$

The research findings also indicate the pharmacist-in the Brebes basically already know

17 Mella Ismelina Farma Rahayu, "Keadilan Ekologis dalam Gugatan Class Action Tempat Pembuangan Akhir Leuwigajah (Kajian Putusan Nomor 145/Pdt.G/2005/PN. Bdg)", Jurnal Yudisial, Vol. V No. 01, April 2012, Jakarta: Mahkamah Konstitusi, page 27. the regulations regarding the standard of pharmacy services in the pharmacy, in the implementation found the constraints that come from inside or outside. Constraints from inside, is the commitment and motivation from the pharmacist itself, the constraints from outside is intervention from the owner of pharmacy facilities. Explicitly and implicitly justice becomes difficult to achieve, and in the science of law that justice is an idea and purpose of the law, but definitely and grammatically justice can not be defined by law science, therefore justice must be assessed from the standpoint of theoretical and philosophical. ${ }^{18}$ The Law is loaded with value, the idea for building a new culture that more contextual to public sense of justice. ${ }^{19} \mathrm{Es}$ pecially considering in the era of tight competition enters the ASEAN Economic Community (AEC) legal norms must be present in order to achieve the desired aim, the demands of increasing competition in product competition both goods and services, ${ }^{20}$ become a threat that counter-productive if in this case, the government does not give assurances and protection as well as referrals or restriction in the constitution implementation of AEC.

\section{Conclusion}

Implementation from standard of pharmacy services at a pharmacy has not running optimally, this condition backed by several reasons of law and socio-economic factors, namely the understanding and knowledge of the law is lacking, this affects the weak of law awareness, the limited number of human resources pharmacy, the factors of ownership pharmacy and economic factors.

18 Bahder Johan Nasution, “Kajian Filosofis tentang Konsep Keadilan dari Pemikiran Klasik sampai Pemikiran Modern", Jurnal Hukum Yustisia, edition 89 Year XXIII, May-August 2014, Surakarta: Faculty of Law Universitas Sebelas Maret, page 119.

19 A. Sukris Sarmadi, Membebaskan Positivisme Hukum ke Ranah Hukum Progresif (Studi Pembacaan Teks Hukum bagi Penegak Hukum)", Jurnal Dinamika Hukum, Vol.12 No. 2. May 2012, Purwokerto: Faculty of Law Universitas Jenderal Soedirman, page 335.

20 Oly Viana Agustine, "Konstitusi Ekonomi menghadapi Masyarakat Ekonomi ASEAN (MEA) Tahun 2015", Jurnal Konstitusi, Vol. 11 No. 4, December 2014, Jakarta: Mahkamah Konstitusi, page778. 
Legal culture of the pharmacist in implementation the standard of pharmacy services at a pharmacy for the protection of patient safety legal culture of apathy that resulted in the application of Health Minister Regulation No. 35 of 2014 is directed to those aspects of interest to benefit from the aspect of legal certainty, this meaning that aspects of legal certainty is not met, but prefer to meet only benefit the parties ie the pharmacist, patients and pharmacy owners.

\section{Suggestion}

First, education and socialization for the pharmacist and Pharmacy Owner Facility must be done in order to enforceability the legal norms standard pharmacy services at a pharmacy. The aims is to have same vision, mission and perceptions in running and managing pharmacy. Second, The Department of Health and Indonesian Pharmacist Association (IAI) are always coordinate in conducting training, supervision, and enforcement to the pharmacist and Owner Facility Pharmacy that not running standard pharmacy services at a pharmacy for the protection of patient safety, as mandated in Health Minister Regulation No. 35 Year 2014.

\section{References}

Agustine, Oly Viana. "Konstitusi Ekonomi menghadapi Masyarakat Ekonomi ASEAN (MEA) Tahun 2015". Jurnal Konstitusi. Vol. 11 No. 4. December 2014. Jakarta: Mahkamah Konstitusi;

Alawiya, Nayla. Aryuni Yuliantiningsih. Dessi Perdani Yuris Puspita Sari. "Hospital Supervisory Board Role in Medical Dispute Settlement in Hospital (Analysis toward Mechanism and Normative Obstacles)". Jurnal Dinamika Hukum. Vol. 15 No. 3. September 2015. Purwokerto: Faculty of Law Universitas Jenderal Soedirman;

Artadi, Ibnu. "Dekonstruksi Pemahaman Penyelesaian Sengketa Bisnis (Ekonomi dan Keuangan) Beraspek Pidana melalui Prosedur Perdamaian: Menuju Proses Peradilan Pidana Rekonsiliatif". Jurnal Hukum Responsif. Vol. 1. No. 1. 2011. Cirebon: Faculty of Law Universitas `Swadaya Gunung Jati Cirebon;
Atmasasmita, Romli."Tiga Paradigma Hukum dalam Pembangunan Nasional". Jurnal Hukum Prioris. Vol. 3 No.1. Year 2012. Jakarta: Faculty of Law Universitas Trisakti;

Bureni, Yunus. "Moralitas Pembentukan Peraturan Daerah dalam Upaya Mencapai Keadilan Substantif (Morality Formation of Local Regulations in An Effort to Ensure Substantive Justice)". Jurnal Legislasi Indonesia. Vol. 10 No. 2. June 2013. Jakarta: Direktorat Jenderal Peraturan Perundang-undangan Kementerian Hukum dan HAM RI;

Dayanto. "Rekonstruksi Paradigma Pembangunan Negara Hukum Indonesia Berbasis Pancasila". Jurnal Dinamika Hukum. Vol. 13 No. 3. September 2013. Purwokerto: Faculty of Law Universitas Jenderal Soedirman;

Kristiana, Yudi. "Ketika Hukum Tidak Lagi Otentik". Jurnal Hukum Supremasi. Vol. IV. No. 1. Oktober 2010- March 2011. Jakarta: Pusat Studi Hukum Bisnis Fakultas Hukum Universitas Sahid;

Nasution, Bahder Johan. "Kajian Filosofis tentang Konsep Keadilan dari Pemikiran Klasik sampai Pemikiran Modern". Jurnal Hukum Yustisia. edition 89 Year XXIII. MayAugust 2014. Surakarta: Faculty of Law Universitas Sebelas Maret;

Prentha, Bahria. "Filsafat Hukum dan Nilai-Nilai Pancasila". Jurnal Ilmiah Kebijakan Hukum. Vol. 5 No. 2 August 2011. Jakarta: Pusat Pengkajian dan Pengembangan Kebijakan Kementerian Hukum dan HAM Rl;

Rahayu, Mella Ismelina Farma. "Keadilan Ekologis dalam Gugatan Class Action Tempat Pembuangan Akhir Leuwigajah (Kajian Putusan Nomor 145/Pdt.G/2005/PN. Bdg)". Jurnal Yudisial. Vol. V No. 01. April 2012. Jakarta: Mahkamah Konstitusi;

Sarmadi, A. Sukris. Membebaskan Positivisme Hukum ke Ranah Hukum Progresif (Studi Pembacaan Teks Hukum bagi Penegak Hukum)". Jurnal Dinamika Hukum. Vol.12 No. 2 May 2012. Purwokerto: Faculty of Law Universitas Jenderal Soedirman;

Sutrisno, Endang. "Implementasi Pengelolaan Sumber Daya Pesisir Berbasis Pengelolaan Wilayah Pesisir Secara Terpadu untuk Kesejahteraan Nelayan (Studi di Perdesaan Nelayan Cangkol Kelurahan Lemahwungkuk Kecamatan Lemahwungkuk Kota Cire- 
bon)". Jurnal Dinamika Hukum. Vol. 14. No. 1. January 2014. Purwokerto: Faculty of Law Universitas Jenderal Soedirman Purwokerto;

Sutrisno, Endang. "Role of law in construction and development of small scale industries through normative perspective". Jurnal Dinamika Hukum. Vol. 15 No. 3. September 2015. Purwokerto: Faculty of Law Universitas Jenderal Soedirman;

Sutrisno, Endang. "Tracing the Performance of Law in Indonesia (A Perspective of Thomas Kuhn's), Normal Science-Journal of Law Policy and Globalization. International Institute for Science. Technology \&
Education Accelerating Global Knowledge Creation and Sharing. Vol. 37. Year 2015;

Warassih, Esmi. 2014. Pranata Hukum Sebuah Telaah Sosiologis. Semarang: Suryandaru Utama;

Widjojanto, Bambang. “Negara Hukum. Korupsi dan Hak Asasi Manusia: Suatu Kajian Awal”. Jurnal Hukum Prioris. Vol. 3 No. 1 2012. Jakarta: Faculty of Law Universitas Trisakti;

Yasin, Rahman. "Telaah Putusan MK dalam Sengketa PHPU Pilpres 2004 (Perspektif Negara Demokrasi Konstitusional)". Jurnal Konstitusi. Vol. 11 No. 4. December 2014. Jakarta: Mahkamah Konstitusi Republik Indonesia. 